\title{
Biological Treatment of Synthetic Oilfield-Produced Water in Activated Sludge Using a Consortium of Endogenous Bacteria Isolated from A Tropical Area
}

\author{
Edwan Kardena*, Syarif Hidayat, Silvia Nora and Qomarudin Helmy \\ Faculty of Civil and Environmental Engineering, Bandung Institute of Technology, Bandung 40132, Indonesia
}

\begin{abstract}
The aim of this study was to investigate the biological treatment of synthetic oilfield-produced water in activated sludge in an attempt to remove the organic compounds using endogenous bacteria; we also hope to determine the biokinetic coefficients. The activated sludge was operated with various hydraulic retention times (HRT=20 hours, 12 hours, 8 hours), solid retention times (SRT=25 days, 20 days, 15 days, 10 days), and substrate concentrations (500 $\mathrm{mg} \mathrm{L}^{-1}$ to $1,100 \mathrm{mg} \mathrm{L}^{-1}$ ). The endogenous bacterial strains, which were isolated from existing wastewater treatment facilities, were identified as Pseudomonas sp., Enterobacter sp., Bacillus sp1., and Bacillus sp2. It was observed that the highest COD removals were obtained in reactors A $(80.7 \%)$ and B $(82.4 \%)$, which had high SRTs (25 days and 20 days) and HRT (20 hours). At shorter SRTs (15 days and 20 days), the concentration of the COD effluent did not comply with the Indonesian regulations for oilfield-produced water quality standards, which means that these SRTs were not recommended as appropriate operational conditions. Furthermore, the results showed that the yield $(\mathrm{Y})$, decay coefficient $(\mathrm{kd})$, maximum specific growth rate $(\mathrm{k})$, and saturation constant $\left(\mathrm{K}_{\mathrm{s}}\right)$ were $0.533 \mathrm{mg} \mathrm{MLVSS} \mathrm{mg}^{-1}$ COD, 0.167 day $^{-1}, 0.985$ day $^{-1}$, and $255.46 \mathrm{mg} \mathrm{COD} \mathrm{L}^{-1}$, respectively. These biokinetic coefficients (obtained from the $\mathrm{Y}$ and $\mathrm{K}$ values) indicated that although the strains of bacteria can grow well in the reactor, they had low affinities to the substrate, which caused the concentration of the COD effluent to be relatively high.
\end{abstract}

Keywords: Petrochemical wastewater; Petroleum hydrocarbon; Oildegrading bacteria; Biokinetic coefficients; Endogenous bacteria

\section{Introduction}

Oilfield-produced water is a byproduct of drilling activities that occurs when extracted oil and gas are carried out; it includes formation water, injection water, and chemicals that are used for the drilling and/ or separation of water and oil. The major compounds of these waters include dissolved and dispersed oil compounds, dissolved formation minerals, production chemical compounds, and production solids [1]. In the oil and gas industry, the oilfield-produced water makes up more than $80 \%$ of the total volume of waste that is generated; it is becoming a major problem because the amount of oilfield-produced water typically increases from year to year and it represents an environmental hazard $[2,3]$.

Options for oilfield-produced water management include discharging the waste into water bodies or using a well re-injection process for oil-enhanced recovery and other beneficial re-uses. Nowadays, many countries have implemented stringent regulations for discharging oilfield-produced water, especially with regards to organic compounds. For example, the Indonesian government has changed the regulations for oilfield-produced water quality standards from sitebased regulations to terminal-based regulations. As a consequence, every offshore oil exploration that purifies crude oil onshore must pay attention to the organic compound parameters; these were not considered in the previous standard [4]. In another case, the European standard sets a very low allowable concentration of the total petroleum hydrocarbon $\left(<5.0 \mathrm{mg} \mathrm{L}^{-1}\right)$ for treated oilfield-produced water from onshore petroleum activities. Several physico-chemical treatments, including coagulation and flocculation [5], reverse osmosis [6], and membrane nanofiltration [7], have been applied for the removal of organic compounds from oilfield-produced water. However, most of these technologies are energy-consuming and only suitable for in situ reuse. Additionally, they have several problems related to their operation, maintenance, and secondary waste stream [8]. Thus, to comply with water body quality standards and avoid generating secondary waste byproducts, a more effective and efficient technology should be used to treat this wastewater.
In the last few years, many researchers have investigated biological treatments in attempts to treat organic compounds/oil-contaminated wastewater. These methods are appealing because they are cost effective, environmentally friendly, and they have high removal efficiencies. However, since oilfield-produced water contains toxic substances that can inhibit bacterial activity, the application of appropriate bacteria is important. Several strains of bacteria, including Pseudomonas, Marinobacter, Halomonas, Aeromonas, Bacillus, Ochrobactrum, Achromobacter, and Rhodococcus, have shown good performance in the removal of organic compounds in oil-contaminated wastewater [9-12]. It has been reported that the performances of these bacteria depend on the concentration of petroleum hydrocarbon [2], the salinity/total dissolved solid (TDS) concentration [9], the nutrient composition [13], and other environmental conditions. Alternatively, the solid retention time (SRT) [14] and hydraulic retention time (SRT) [15] are also considered to be critical operating parameters that affect the performance of biological treatment processes. In most cases, the SRT and HRT influence the removal efficiency of organic compounds, the structure and physical characteristics of sludge, the composition, and the activity of bacteria.

Although several studies have been carried out investigating the treatment of oilfield-produced water with activated sludge, the values of biokinetic coefficients are not widely available. Therefore, in order

Corresponding author: Edwan Kardena, Faculty of Civil and Environmental Engineering, Bandung Institute of Technology, Bandung 40132, Indonesia, Tel: +62 22 2500935; E-mail: kardena@pusat.itb.ac.id

Received May 29, 2017; Accepted June 25, 2017; Published June 30, 2017

Citation: Kardena E, Hidayat S, Nora S, Helmy Q (2017) Biological Treatment of Synthetic Oilfield-Produced Water in Activated Sludge Using a Consortium of Endogenous Bacteria Isolated from A Tropical Area. J Pet Environ Biotechnol 7 : 331. doi: 10.4172/2157-7463.1000331

Copyright: (c) 2017 Kardena E, et al. This is an open-access article distributed under the terms of the Creative Commons Attribution License, which permits unrestricted use, distribution, and reproduction in any medium, provided the original author and source are credited. 
Citation: Kardena E, Hidayat S, Nora S, Helmy Q (2017) Biological Treatment of Synthetic Oilfield-Produced Water in Activated Sludge Using a Consortium of Endogenous Bacteria Isolated from A Tropical Area. J Pet Environ Biotechnol 7: 331. doi: 10.4172/2157-7463.1000331

Page 2 of 6

to determine the biokinetic coefficients and evaluate the performance of the activated sludge, the degradation of the organic compounds in synthetic oilfield-produced water by endogenous bacteria was investigated in this study. The endogenous bacteria, which were isolated from existing oilfield-produced water treatment facilities, were used as organic-degrading bacteria. The activated sludge was operated with different HRTs, SRTs, and initial concentrations of organic compounds. Furthermore, biochemical tests were conducted to identify the selected bacteria.

\section{Materials and Methods}

\section{Characteristics of oilfield-produced water}

Samples of oilfield-produced water were taken from an Indonesian oilfield located in Balikpapan; these were used to perform screening and kinetic growth tests for the bacteria. In the other hand, the synthetic oilfield-produced water was used throughout our study to determine the capability of strains of bacteria to degrade organic compounds. The synthetic oilfield-produced water was prepared by mixing crude oil $\left(1.5 \mathrm{~mL} \mathrm{~L}^{-1}\right)$ and salt water (real sea water and tap water) in a container, as described in the literature $[12,16]$. The $\mathrm{C} / \mathrm{N} / \mathrm{P}$ ratio of the medium was adjusted to approximately $100 / 5 / 1$ by adding appropriate concentrations of $\left(\mathrm{NH}_{4}\right)_{2} \mathrm{SO}_{4}$ and $\mathrm{KH}_{2} \mathrm{PO}_{4}$ to the synthetic oilfieldproduced water. This synthetic oilfield-produced water was used throughout our study to determine the capability of isolated strains of bacteria to degrade organic compounds. The characteristics of the real and synthetic oilfield-produced water samples are listed in Table 1.

\section{Growth medium}

A standard basal salts (SBS) medium was used as the bacterial growth medium; this contained $\mathrm{K}_{2} \mathrm{HPO}_{4}(1.5 \mathrm{~g}), \mathrm{KH}_{2} \mathrm{PO}_{4}(0.5 \mathrm{~g})$, $\mathrm{MgSO}_{4}(0.2 \mathrm{~g}),\left(\mathrm{NH}_{4}\right)_{2} \mathrm{SO}_{4}(0.5 \mathrm{~g})$, yeast extract $(0.5 \mathrm{~g})$, and $1 \mathrm{~mL}$ of a trace-element solution in $1 \mathrm{~L}$ of distilled water. The $\mathrm{pH}$ of this medium was adjusted to 7.0. The real oilfield-produced water was added as a carbon source at $2.0 \%\left(\mathrm{v} \mathrm{v}^{-1}\right)$. The SBS solid medium was prepared by adding $5 \mathrm{~g} \mathrm{~L}^{-1}$ of bacto agar. All media and solutions were sterilized with an autoclave at $121^{\circ} \mathrm{C}$ for $20 \mathrm{~min}$.

\section{Isolation and identification of bacteria}

The samples for inoculum were isolated from the existing units of oilfield-produced water treatment facilities; these included the dissolved air flotation (DAF) unit (strain-D), sediment (strain-S), inlet (strain-I), and outlet (strain-O). Cultures of the strains of bacteria were obtained by inoculating $5.0 \mathrm{~mL}$ of each sample into a $500 \mathrm{~mL}$ SBS liquid medium. These were then incubated at $30^{\circ} \mathrm{C}$ and stirred at $120 \mathrm{rpm}$ for six days, $10 \mathrm{~mL}$ of the previous enrichment cultures were inoculated into fresh liquid SBS with $2.0 \%\left(\mathrm{v} \mathrm{v}^{-1}\right)$ of real oilfieldproduced water and cultivated under the same conditions. After four cycles of enrichment, $1.0 \mathrm{~mL}$ of each culture was serially diluted $\left(10^{-1}\right.$ to $10^{-7}$ ), spread on the surface of the SBS solid medium, and incubated at $30^{\circ} \mathrm{C}$ for three days, $500 \mu \mathrm{L}$ of sterile, real oilfield-produced water was spread on the surface of the plates as the sole source of carbon. The predominance of a single colony was picked out and inoculated

\begin{tabular}{|c|c|c|c|c|c|}
\hline \multirow{2}{*}{ Parameters } & \multirow{2}{*}{ Unit } & \multicolumn{4}{|c|}{ Oilfield-produced water } \\
\cline { 3 - 6 } & & Site-1 & Site-2 & Site-3 & Synthetic \\
\hline COD & $\mathrm{mg} \mathrm{L}^{-1}$ & 1,863 & 1,048 & 504.8 & 1,120 \\
\hline pH & $\mathrm{mg} \mathrm{L}^{-1}$ & 7.38 & 7.42 & 7.65 & 6.85 \\
\hline Oil and grease & $\mathrm{mg} \mathrm{L}^{-1}$ & 30.2 & 18.5 & 10.2 & - \\
\hline TDS & $\mathrm{mg} \mathrm{L}^{-1}$ & 8,800 & 6,125 & 5,125 & 11,000 \\
\hline
\end{tabular}

Table 1: Characteristic of real and synthetic of oilfield produced water. in a fresh SBS liquid medium supplemented with $2.0 \%$ of oilfieldproduced water as the carbon source; this was subsequently incubated for two days. The colony and cell morphology of the selected bacteria were determined using macroscopic, microscopic, and motility tests. The bacterial strains were identified by classical methods, as outlined by Cowan and Steele's manual for the identification of medical bacteria [17] and Bergey's manual on systematic bacteriology [18].

\section{Biodegradation potential}

In order to assess the biodegradation potential of organic compounds by the selected bacteria, the bacteria were tested with three different types of real oilfield-produced water (Site-1, Site-2, and Site-3). The degradation potential was based on the specific growth rate $(\mu)$ and chemical oxygen demand (COD) removal efficiency. To make a growth curve, $2.0 \mathrm{~mL}$ samples were taken and the optical density (OD) of the media was measured every $1.0 \mathrm{~h}$ to $2.0 \mathrm{~h}$ using a spectrophotometer. The absorbance was measured at $600 \mathrm{~nm}$ against a blank sample $(2.0$ $\mathrm{mL}$ of the produced water). The growth curve was obtained by plotting the OD versus the observation time $(t)$. By using the general equation of the $1^{\text {st }}$ order kinetics reaction, we can obtain the specific growth rate of bacteria $(\mu)$ in the exponential phase. The initial and final CODs were measured using standard methods (DR-2800, Hach Company).

\section{Bioreactor design/operation and determination of the biokinetic coefficients}

The schematic diagram of the experimental set-up for the activated sludge system is shown in Figure 1. The aeration tank and clarifier were made of acrylic glass with $7.0 \mathrm{~L}$ and $10.0 \mathrm{~L}$ working volumes, respectively. In order to maintain the dissolved oxygen (DO) in the system $\left(\mathrm{DO}>4.0 \mathrm{mg} \mathrm{L}^{-1}\right)$, air was supplied to the aeration tank by a blower through the diffused aerator. The synthetic oilfield-produced water was fed continuously into the bioreactor as the sole carbon source for the microbial population growth. Peristaltic pumps were used to maintain the desired hydraulic retention time (HRT) and solid retention time (SRT) in the system.

The system operation was divided into two stages: (1) an acclimation period and (2) a treatment period. During the acclimation period, the activated sludge was first operated with the batch conditions for approximately 20 days. During this period, the activated sludge was fed with a COD concentration of $1040 \mathrm{mg} \mathrm{L}^{-1}$ to $1170 \mathrm{mg} \mathrm{L}^{-1}$. The treatment period was carried out in four different reactors (reactors A, B, C, and D) with SRTs of 25 days, 20 days, 15 days, and 10 days and HRTs of $8 \mathrm{~h}$, $12 \mathrm{~h}$, and $20 \mathrm{~h}$ for each SRT, respectively (with $100 \%$ return sludge). The average initial concentration for each HRT was $1000 \mathrm{mg} \mathrm{L}^{-1}, 700 \mathrm{mg} \mathrm{L}^{-1}$, and $500 \mathrm{mg} \mathrm{L}^{-1}$. The performance of the activated sludge was monitored by analyzing the COD and biomass in the system.

The biokinetic coefficients were determined according to the following equations [19]:

$$
\begin{aligned}
& \frac{1}{\grave{\mathrm{e}}_{\mathrm{c}}}=\mathrm{YU}-\mathrm{k}_{\mathrm{d}}=\mathrm{Y} \frac{\mathrm{S}_{\mathrm{o}}-\mathrm{S}_{\mathrm{e}}}{\grave{\mathrm{e}}_{\mathrm{h}} \mathrm{X}}-\mathrm{k}_{\mathrm{d}}, \\
& \frac{1}{\mathrm{U}}=\left(\frac{\mathrm{K}_{\mathrm{s}}}{\mathrm{k}}\right)\left(\frac{1}{\mathrm{~S}_{\mathrm{o}}}\right)+\frac{1}{\mathrm{k}} .
\end{aligned}
$$

Here, $\theta$ is the solid retention time (day), $\mathrm{Y}$ is the biomass yield (mg MLVSS $\mathrm{mg}^{-1} \mathrm{COD}$ ), $\mathrm{U}$ is the substrate utilization rate (mg COD $\mathrm{mg}^{-1}$ MLVSS day $\left.{ }^{-1}\right), \mathrm{k}_{\mathrm{d}}$ is the endogenous decay coefficient $\left(\right.$ day $\left.^{-1}\right), \mathrm{S}_{\mathrm{o}}$ is the influent substrate concentration $\left(\mathrm{mg} \mathrm{COD} \mathrm{L}^{-1}\right), \mathrm{S}$ is the effluent substrate concentration $\left(\mathrm{mg} \mathrm{COD} \mathrm{L}^{-1}\right), \mathrm{X}$ is the biomass concentration 
Citation: Kardena E, Hidayat S, Nora S, Helmy Q (2017) Biological Treatment of Synthetic Oilfield-Produced Water in Activated Sludge Using a Consortium of Endogenous Bacteria Isolated from A Tropical Area. J Pet Environ Biotechnol 7: 331. doi: 10.4172/2157-7463.1000331

Page 3 of 6

(mg MLVSS $\left.\mathrm{L}^{-1}\right), \theta_{\mathrm{h}}$ is the hydraulic retention time $(\mathrm{d}), \mathrm{K}_{\mathrm{s}}$ is the halfvelocity constant ( $\mathrm{mg}$ COD $\mathrm{mg}^{-1} \mathrm{MLVSS}$ ), and $\mathrm{k}$ is the maximum rate of substrate utilization (mg COD $\mathrm{mg}^{-1}$ MLVSS).

\section{Results and Discussion}

\section{Isolation and identification of bacteria}

Four bacterial strains were isolated from existing oilfieldproduced water treatment facilities by enriching the cultures and performing dilution plate separation. The isolated bacterial strains were characterized by their colony, cell morphology, and biochemical characteristics (Table 2). Based on the data obtained from the colony morphology tests, selected bacteria were observed to be circular in shape with curled edges. They were also unpigmented or pigmented with shiny-yellow and cream colors. The cell morphologies of the bacteria were in the form of rods in chains, spore-forming or nonspore-forming, and motile with flagella. Two strains were Grampositive and two strains were Gram-negative.

According to the data obtained from biochemical testing, the selected bacteria were closely related to Pseudomonas sp., Enterobacter sp., Bacillus sp., and Bacillus sp. for strain-D, strain-S, strain-O, and strain-I, respectively. Bacteria of the genera Pseudomonas, Enterobacter, and Bacillus have been widely reported as bacteria that can degrade the organic compounds in petroleum oil and gas wastes, including oilfieldproduced water [9,20], soil contaminated with hydrocarbons [21-24], and wastewater contaminated with hydrocarbons [10]. A recent study reported that the genus Enterobacter also has the ability to degrade the biopolymers that are used in oil-recovery processes [25]. Furthermore, it is well known that these strains can synthesize bioemulsifiers, which can enhance the bioavailability of hydrocarbon as a carbon source $[26,27]$. Strains that have genes involved in bioemulsifier synthesis and regulation are versatile for the degradation, emulsification, and metabolizing of hydrocarbons [28].

\section{Biodegradation potential of organic compounds by a bacterial strain}

To determine the biodegradation potential, mixed cultures of the selected bacteria were tested in three different types of real oilfieldproduced water (water from Site-1, Site-2, and Site-3). The COD and TDS concentrations of these oilfield-produced water samples varied

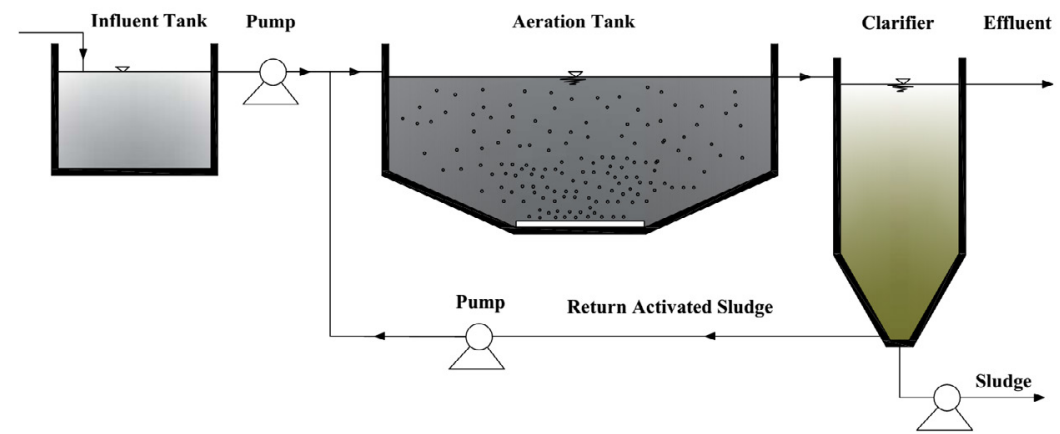

Figure 1: Schematic diagram of experimental set-up for the activated sludge.

\begin{tabular}{|c|c|c|c|c|c|}
\hline \multirow{2}{*}{ Characteristics } & \multirow{2}{*}{ Tests } & \multicolumn{4}{|c|}{ Results } \\
\hline & & Strain-D & Strain-S & Strain-O & Strain-I \\
\hline \multirow{3}{*}{$\begin{array}{l}\text { Colony and cell } \\
\text { morphology }\end{array}$} & Macroscopic & $\begin{array}{l}\text { Circular, Entire, Convex, Pigmented, } \\
\text { Shiny yellow (fluorescent), Translucent }\end{array}$ & $\begin{array}{l}\text { Circular, Entire, Convex, } \\
\text { Unpigmented, Transparent }\end{array}$ & $\begin{array}{l}\text { Circular, Curled, Raised, } \\
\text { Unpigmented, Opaque }\end{array}$ & $\begin{array}{c}\text { Circular, Entire, Convex, } \\
\text { Pigmented, Cream, Opaque }\end{array}$ \\
\hline & Microscopic & Rod, Gram (-), Non-endospore forming & $\begin{array}{l}\text { Rod, Gram (-), Non- } \\
\text { endospore forming }\end{array}$ & $\begin{array}{l}\text { Rod, Gram (+), Endospore } \\
\text { forming }\end{array}$ & $\begin{array}{l}\text { Rod, Gram (+), Endospore } \\
\text { forming }\end{array}$ \\
\hline & Motility & Motile & Motile & Motile & Motile \\
\hline \multirow{16}{*}{ Biochemical } & Starch hydrolysis & $(-)$ & $(-)$ & $(+)$ & $(-)$ \\
\hline & Fat hydrolysis & $(-)$ & $(-)$ & $(-)$ & $(-)$ \\
\hline & Casein hydrolysis & $(+)$ & $(-)$ & $(+)$ & $(-)$ \\
\hline & Gelatin hydrolysis & $(+)$ & $(-)$ & $(+)$ & $(-)$ \\
\hline & Glucose fermentation & $(+)$ & $(+)$ & $(+)$ & $(-)$ \\
\hline & Sucrose fermentation & $(-)$ & $(-)$ & $(-)$ & $(-)$ \\
\hline & Lactose fermentation & $(-)$ & $(-)$ & $(-)$ & $(-)$ \\
\hline & $\mathrm{H}_{2} \mathrm{~S}$ production & $(-)$ & $(-)$ & $(-)$ & $(-)$ \\
\hline & Indol production & $(+)$ & $(+)$ & $(-)$ & $(-)$ \\
\hline & Urease production & $(+)$ & $(+)$ & $(+)$ & $(+)$ \\
\hline & Catalase production & $(+)$ & $(+)$ & $(+)$ & $(+)$ \\
\hline & Metil red & $(+)$ & $(+)$ & $(+)$ & $(-)$ \\
\hline & Voges-Proskauer & $(-)$ & $(-)$ & $(-)$ & $(-)$ \\
\hline & Triple sugar iron & $(+)$ & $(+)$ & $(+)$ & $(-)$ \\
\hline & Simmon's citrate agar & $(+)$ & $(+)$ & $(-)$ & $(-)$ \\
\hline & Nitrate reduction & $(+)$ & $(+)$ & $(+)$ & $(-)$ \\
\hline \multicolumn{2}{|c|}{ Conclusion* } & Pseudomonas sp. & Enterobacter sp. & Bacillus sp1. & Bacillus sp2. \\
\hline
\end{tabular}

*Bergey's Manual of Systematic Bacteriology

Table 2: Colony and cell morphology and biochemical characteristics of selected bacterial strain. 
Citation: Kardena E, Hidayat S, Nora S, Helmy Q (2017) Biological Treatment of Synthetic Oilfield-Produced Water in Activated Sludge Using a Consortium of Endogenous Bacteria Isolated from A Tropical Area. J Pet Environ Biotechnol 7: 331. doi: 10.4172/2157-7463.1000331

Page 4 of 6

from $505 \mathrm{mg} \mathrm{L}^{-1}$ to $1,863 \mathrm{mg} \mathrm{L}^{-1}$ and $5,125 \mathrm{mg} \mathrm{L}^{-1}$ to $8,800 \mathrm{mg} \mathrm{L}^{-1}$, respectively. Recent research states that the concentrations of organic compounds and TDSs in oilfield-produced water can be affected by the biodegradation capability of bacteria [9]. They can inhibit the bacterial production of enzymes and cause cell plasmolysis, leading to low organic removal efficiencies. In this study, the strains of bacteria seem to adapt well in the oilfield-produced water because there is no indication of any inhibitory effects during the degradation test. The curve of growth shows that the strains of bacteria can grow very well in the oilfield-produced water (Figure 2). The strains of bacteria tend to grow and reach the exponential phase after $5 \mathrm{~h}$ of incubation, which indicates that the strains of bacteria can consume organic compounds in the oilfield-produced water as a carbon source as soon as they come into contact with the wastewater. It was reported that endogenous bacteria can grow and adapt well to the target contaminants and/or to extreme conditions due to their environmental suitability [11].

The value of the specific growth rate $(\mu)$ and COD removal after four days of incubation for each site were $5.42 \mathrm{day}^{-1}, 5.23 \mathrm{day}^{-1}$, and 4.37 day $^{-1}$ and $81.1 \%, 77.3 \%$, and $64.3 \%$, respectively (Table 3 ). The specific growth rate $(\mu)$ and COD removal of the strains of bacteria tended to

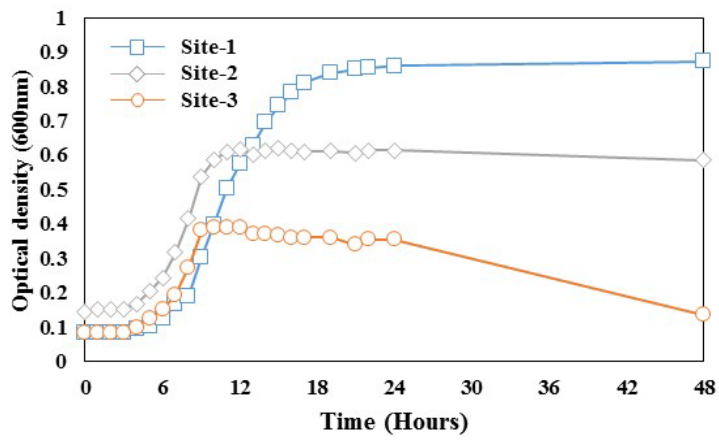

Figure 2: Growth of selected bacteria in the three different types of real oilfieldproduced water.

\begin{tabular}{|c|c|c|c|c|}
\hline \multirow{2}{*}{ Parameters } & \multirow{2}{*}{ Unit } & \multicolumn{3}{|c|}{ Oilfield-produced water } \\
\cline { 3 - 5 } & & Site-1 & Site-2 & Site-3 \\
\hline Specific growth rate (k) & day $^{-1}$ & 5.42 & 5.23 & 4.37 \\
\hline COD removal & $\%$ & 81.1 & 77.3 & 64.3 \\
\hline
\end{tabular}

Table 3: Specific growth rate $(\mu)$ and COD removal of selected bacteria in different types of oilfield-produced water.

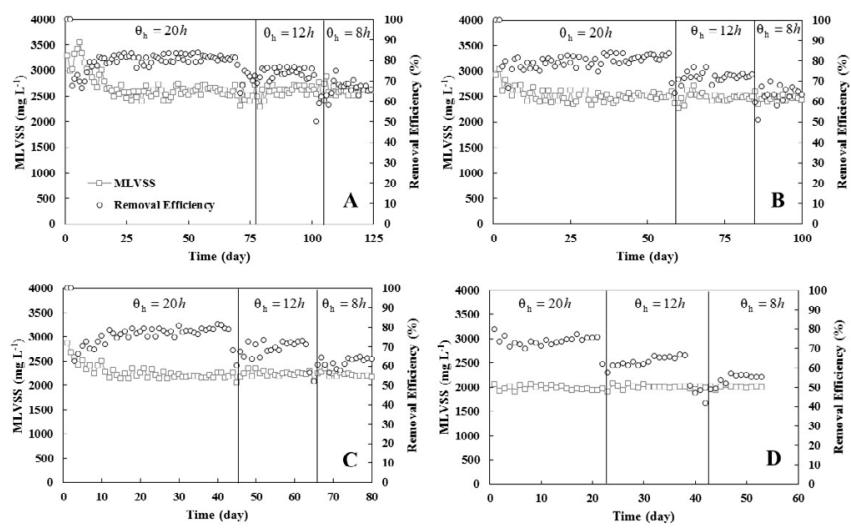

Figure 3: Profile of COD removal and MLVSS concentration of activated sludge system for oilfield-produced water treatment at (A) 25 days, (B) 20 days, (C) 15 days, and (D) days of SRT and different HRT (20 h, $12 \mathrm{~h}, 8 \mathrm{~h})$.

\begin{tabular}{|c|c|c|c|c|}
\hline No. & SRT (day) & HRT (hours) & MLVSS (mg L-1) & $\operatorname{Se}\left(\mathrm{mg} \mathrm{L}^{-1}\right)$ \\
\hline 1 & \multirow{3}{*}{25} & 20 & 2586 & 194 \\
\hline 2 & & 12 & 2653 & 179 \\
\hline 3 & & 8 & 2637 & 172 \\
\hline 4 & \multirow{3}{*}{20} & 20 & 2504 & 180 \\
\hline 5 & & 12 & 2483 & 190 \\
\hline 6 & & 8 & 2467 & 180 \\
\hline 7 & \multirow{3}{*}{15} & 20 & 2192 & 208 \\
\hline 8 & & 12 & 2241 & 199 \\
\hline 9 & & 8 & 2199 & 191 \\
\hline 10 & \multirow{3}{*}{10} & 20 & 1950 & 265 \\
\hline 11 & & 12 & 2000 & 260 \\
\hline 12 & & 8 & 2000 & 250 \\
\hline
\end{tabular}

Table 4: The concentration of MLVSS and COD effluent at the treatment period.

increase as the initial COD concentration in the oilfield-produced water increased. It was assumed that the activity of the strains of bacteria in the oilfield-produced water was higher with higher COD concentrations than that with lower concentrations due to the high availability of the substrate. The $\mu$ value achieved in this study was slightly greater than or less than those reported by Tellez et al. [29] and Talaie et al. [30]. It is well known that the $\mu$ value depends on the type and composition of bacteria as well as on the characteristics of wastewater. In terms of the COD removal, even with an extended incubation time of six days, there was no significant change; the concentration of the final effluent was still high ( $181 \mathrm{mg} \mathrm{L}^{-1}$ to $358 \mathrm{mg} \mathrm{L}^{-1}$ ). This suggested that the oilfieldproduced water had a lack of nutrients (nitrogen and phosphate). It has been reported that an appropriate composition of nutrients is an important factor in the degradation of organic compounds, especially for hydrocarbon degradation $[12,13]$. A sufficient amount of nutrients in the wastewater can stimulate the bacteria activity, leading to high removal of the targeted contaminants.

\section{Bioreactor performance and biokinetic determination}

The reactor was acclimated for 20 days using batch conditions with an initial COD concentration of $1.040 \mathrm{mg} \mathrm{L}^{-1}$ to $1.170 \mathrm{mg} \mathrm{L}^{-1}$. During the first three days of the acclimation period, the average COD removal was $38.7 \%$. This value increased to $83.4 \%$ after 10 days (data not shown). The COD concentration of the effluent remained below 162 $\mathrm{mg} \mathrm{L}^{-1}$ during the remainder of the acclimation period. The acclimation period becomes important as the bacteria undergo phase adaptation in a new environment on the substrate. These results indicated that the selected bacteria were acclimatized such that they could use the organic compounds in the synthetic oilfield-produced water as a carbon source [10].

The performance of the activated sludge in the treatment period can be seen in Table 4 and Figure 3. It was observed that, at the beginning of each phase, the concentration of MLVSS decreased. However, the system reached a steady-state condition after a few days and became more adapted to the new environment as a function of time. In the steady-state condition, the highest MLVSS concentration was observed in reactor A (approximately $2.586 \mathrm{mg} \mathrm{L}^{-1}$ to $2.653 \mathrm{mg} \mathrm{L}^{-1}$ ) while the lowest concentration was found in reactor $\mathrm{D}$ (approximately $1.950 \mathrm{mg}$ $\mathrm{L}^{-1}$ to $\left.2.000 \mathrm{mg} \mathrm{L}^{-1}\right)$. The average MLVSS concentrations of reactors $\mathrm{A}$, B, C, and D (SRT: 25 days, 20 days, 15 days, and 10 days) were relatively constant but decreased with reduced SRTs (from 25 days to 10 days). This means that, in these experiments, the reduction of the HRT (from 20 to $8 \mathrm{~h}$ ) and initial COD concentration (from $1000 \mathrm{mg} \mathrm{L}^{-1}$ to 500 $\mathrm{mg} \mathrm{L}^{-1}$ ) did not affect the MLVSS concentration in the reactor. These results indicated that the MLVSS concentration in the reactor was controlled by the SRT. A similar trend was observed by Tellez et al. [2] who reported the ability of an activated sludge to remove petroleum 
Citation: Kardena E, Hidayat S, Nora S, Helmy Q (2017) Biological Treatment of Synthetic Oilfield-Produced Water in Activated Sludge Using a Consortium of Endogenous Bacteria Isolated from A Tropical Area. J Pet Environ Biotechnol 7: 331. doi: 10.4172/2157-7463.1000331

Page 5 of 6

hydrocarbons from oilfield-produced water. It was clear that a shorter SRT increases the sludge waste volume, which leads to a decrease in the MLVSS concentration in the reactor.

As observed in Figure 3, the COD removal was decreased at the beginning of each phase but then recovered after a few days. In these experiments, reducing the HRT and initial COD concentration caused a slight increase in the organic loading rate (OLR). Alternatively, increasing the OLR in the bioreactor caused the microorganisms to be faced with a sudden increase in the organic loading, which limited their metabolism and decreased the reactor performance [10,31-33]. However, with respect to time, the microorganisms recovered and adapted to the changed loading conditions and eventually reached steady-state biodegradation [33]. Under steady-state conditions, the concentrations of the COD effluent for each HRT $(20,12,8 \mathrm{~h})$ in reactor A (194 $\left.\mathrm{mg} \mathrm{L}^{-1}, 179 \mathrm{mg} \mathrm{L}^{-1}, 172 \mathrm{mg} \mathrm{L}^{-1}\right), \mathrm{B}\left(180 \mathrm{mg} \mathrm{L}^{-1}, 190 \mathrm{mg}\right.$ $\left.\mathrm{L}^{-1}, 180 \mathrm{mg} \mathrm{L}^{-1}\right), \mathrm{C}\left(208 \mathrm{mg} \mathrm{L}^{-1}, 199 \mathrm{mg} \mathrm{L}^{-1}, 191 \mathrm{mg} \mathrm{L}^{-1}\right)$, and D (265 $\mathrm{mg} \mathrm{L}^{-1}, 260 \mathrm{mg} \mathrm{L}^{-1}$ and $250 \mathrm{mg} \mathrm{L}^{-1}$ ) were slightly decreased as the HRT and initial COD concentration decreased. However, the concentrations of the COD effluent increased as the SRT decreased. These results suggested that the highest COD removal can be obtained with longer HRTs and SRTs. Longer HRTs increase the contact time between the target contaminant and the biomass [32], while longer SRTs cause the MLVSS to be better adapted to the target contaminant [33], leading to improved reactor performance. The highest $\mathrm{COD}$ removal was obtained in reactors $\mathrm{A}$ and $\mathrm{B}$ when an HRT of $20 \mathrm{~h}$ was applied; this produced value close to $80.7 \%$ and $82.4 \%$, respectively. Furthermore, in reactors $\mathrm{C}$ and D (SRTs of 15 days and 10 days), the residual COD in the effluent is still high and does not comply with the Indonesian regulations for oilfield-produced water quality standards. This was consistent with the previous research of Tellez et al. [2], which reported that an SRT of 20 days is the minimum retention time required to degrade the organic compounds contained in oilfield-produced water.
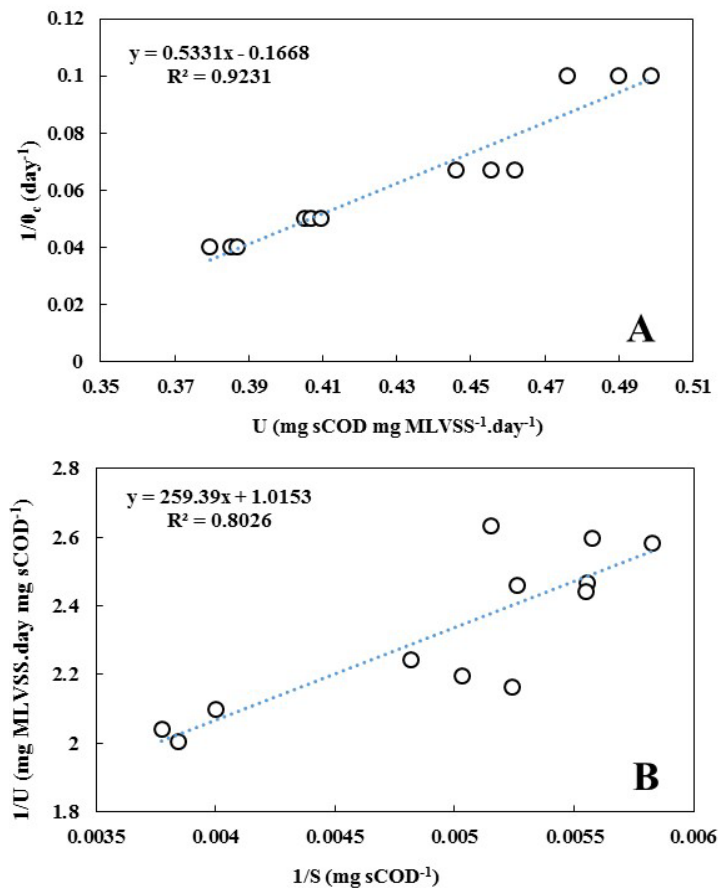

Figure 4: Determination of $(A) Y$ and $k_{d}$ and $(B) K s$ and $k$ values of activated sludge system.
The biokinetic coefficients were determined by Equations (1) and (2). These equations describe the growth of biomass, substrate utilization rates, and mean cell residence time in the activated sludge processes. A plot of $1 / \theta \mathrm{c}$ as a function of the substrate consumption rate $\mathrm{U}$ (Figure $4 \mathrm{~A}$ ) provides the linear regression as the slope and the gradient is the yield. Therefore, the $\mathrm{x}$-intercept is $\mathrm{kd}$. Additionally, a plot of $1 / \mathrm{U}$ as a function of $1 / \mathrm{S}$ (Figure $4 \mathrm{~B}$ ) gives the linear regression as the slope and the gradient is $\mathrm{Ks} / \mathrm{k}$. Therefore, the $\mathrm{x}$-intercept is $\mathrm{kd}$ and the $y$-intercept is $1 / \mathrm{k}$. The values of the yield $(\mathrm{Y})$, decay coefficient $\left(\mathrm{k}_{\mathrm{d}}\right)$, maximum specific growth rate $(\mathrm{k})$, and saturation constant $\left(\mathrm{K}_{\mathrm{s}}\right)$ were $0.533 \mathrm{mg}$ MLVSS mg-1 COD, $0.167 \mathrm{day}^{-1}, 0.985 \mathrm{day}^{-1}$, and 255.46 $\mathrm{mg} \mathrm{COD} \mathrm{L}^{-1}$, respectively. The $\mathrm{Y}, \mathrm{k}_{\mathrm{d}}$, and $\mathrm{K}_{\mathrm{s}}$ values obtained from these experiments were higher than those of the design criteria specified by Tchobanoglous et al. [19]. The $\mathrm{Y}$ and $\mathrm{k}_{\mathrm{d}}$ values represent the sludge production and the biomass lost due to endogenous respiration during the sludge processes, respectively. Therefore, a high Y value indicates a higher sludge production, while a high $\mathrm{k}_{\mathrm{d}}$ value causes a reduced net sludge production [34]. In the process design of a wastewater treatment facility, the $\mathrm{Y}$ and $\mathrm{k}_{\mathrm{d}}$ values play an important role in determining the volume of the reactor of the sludge handling facilities. Meanwhile, the $\mathrm{k}$ value affects the total volume of the reactor; a smaller $\mathrm{k}$ value leads to a greater reactor volume. The $\mathrm{K}_{\mathrm{s}}$ value shows the affinity of the biomass to the substrate; therefore, a concentration of substrate at half of its maximum growth rate. The high $\mathrm{K}_{\mathrm{s}}$ value (255.46 $\mathrm{mg} \mathrm{COD} \mathrm{L}^{-1}$ ) obtained in this experiment indicated that the strains of bacteria have a low affinity for the substrate, which means that the growth rate of the strains of bacteria will be affected by the residuals on the substrate, which are still high.

\section{Conclusion}

Activated sludge with endogenous bacteria was used to treat synthetic oilfield-produced water under different hydraulic retention times (HRT=20 h, $12 \mathrm{~h}, 8 \mathrm{~h}$ ), solid retention times (SRT=25 days, 20 days, 15 days, 10 days), and initial substrate concentrations $(500 \mathrm{mg}$ $\mathrm{L}^{-1}$ to $1,100 \mathrm{mg} \mathrm{L}^{-1}$ ). Through biochemical testing, the endogenous bacteria, which were isolated from existing wastewater treatment facilities, were identified as Pseudomonas sp., Enterobacter sp., Bacillus sp1., and Bacillus sp2. It was observed that the MLVSS concentration was controlled by the SRT, while the COD removal depended on the HRT and SRT. Therefore, due to the high of MLVSS concentration and the long contact time, high removal efficiencies ( $80.7 \%$ and $82.4 \%)$ were obtained with a long HRT (20 hours) and SRT (20 days and 25 days). Meanwhile, at SRTs of 15 days and 10 days, the concentration of the COD effluent did not comply with the Indonesian oilfieldproduced water quality standards. This indicates that these SRTs are not suitable for operational treatment conditions. The values of the biokinetic coefficients obtained from these experiments were $0.533 \mathrm{mg}$ MLVSS mg ${ }^{-1}$ COD, 0.167 day $^{-1}, 0.985$ day $^{-1}$, and $255.46 \mathrm{mg} \mathrm{COD} \mathrm{L}^{-1}$ for the yield $(\mathrm{Y})$, decay coefficient $(\mathrm{kd})$, maximum specific growth rate (k), and saturation constant (Ks), respectively. These results suggested that although the strains of bacteria can grow well in the reactor (as indicated by the high $Y$ value), their low affinity for the substrate causes the COD concentration of the effluent to be relatively high (as indicated by the high Ks value).

\section{References}

1. Fakhru'l-Razi A, Pendashteh A, Abdullah LC, Biak DRA, Madaeni SS, et al. (2009) Review of technologies for oil and gas produced water treatment. J Hazard Mater 170: 530-551.

2. Tellez GT, Nirmalakhandan N, Gardea-Torresdey J (2002) Performance evaluation of an activated sludge system for removing petroleum hydrocarbons from oilfield produced water. Adv Environ Res 6: 455-470. 
Citation: Kardena E, Hidayat S, Nora S, Helmy Q (2017) Biological Treatment of Synthetic Oilfield-Produced Water in Activated Sludge Using a Consortium of Endogenous Bacteria Isolated from A Tropical Area. J Pet Environ Biotechnol 7: 331. doi: 10.4172/2157-7463.1000331

Page 6 of 6

3. Elias-Samlalsingh N, Agard JBR (2004) Application of toxicity identification evaluation procedures for characterizing produced water using the tropical mysid, Metamysidopsis insularis. Environ Toxicol Chem 23: 1194-1203.

4. Helmy Q, Kardena E (2015) Petroleum oil and gas industry waste treatment; common practice in Indonesia. J Pet Environ Biotechnol 6: 241.

5. Zhou FS, Zhao MF, Ni WX, Dang YS, Pu CS, et al. (2000) Inorganic polymeric flocculent FMA for purifying oilfield produced water: Preparation and uses. Oilfield Chem 17: 256-259.

6. Khedr MG (2015) Nanofiltration of oil field-produced water for reinjection and optimum protection of oil formation. Desalin Water Treat 55: 3460-3468.

7. Melo M, Schluter H, Ferreira J, Magda R, Júnior A, et al. (2010) Advanced performance evaluation of a reverse osmosis treatment for oilfield produced water aiming reuse. Desalination 250: 1016-1018.

8. Tong K, Zhang Y, Liu G, Ye Z, Chu PK (2013) Treatment of heavy oil wastewater by a conventional activated sludge process coupled with an immobilized biological filter. Int Biodeterior Biodegrad 84: 65-71.

9. Pendashteh AR, Fakhru'l-Razi A, Chuah TG, Radiah, ABD, Madaeni SS, et al. (2010) Biological treatment of produced water in a sequencing batch reactor by a consortium of isolated halophilic microorganisms. Environ Technol 31: 12291239.

10. Gargouri B, Karray F, Mhiri N, Aloui F, Sayadi S (2011) Application of a continuously stirred tank bioreactor (CSTR) for bioremediation of hydrocarbonrich industrial wastewater effluents. J Hazard Mater 189: 427-434

11. Li Q, Wang M, Feng J, Zhang W, Wang Y, et al. (2013) Treatment of highsalinity chemical wastewater by indigenous bacteria- Bioaugmented contact oxidation. Bioresour Technol 144: 380-386.

12. Sharghi EA, Bonakdarpour B, Roustazade $P$, Amoozegar MA, Rabbani AR (2013) The biological treatment of high salinity synthetic oilfield produced water in a submerged membrane bioreactor using a halophilic bacterial consortium. J Chem Technol Biot 88: 2016-2026.

13. Singh AK, Sherry A, Gray ND, Jones DM, Bowler BFJ, et al. (2014) Kinetic parameters for nutrient enhanced crude oil biodegradation in intertidal marine sediments. Microbiol 5: 160

14. Moussa MS, Hooijmans CM, Lubberding HJ, Gijzen HJ, Van Loosdrecht MCM (2005) Modelling nitrification, heterotrophic growth and predation in activated sludge. Water Res 39: 5080-5098.

15. Kargi F, Uygur A (2003) Nutrient removal performance of a five-step sequencing batch reactor as a function of wastewater composition. Process Biochem 38 : 1039-1045.

16. Tansel B, Regula J, Shalewitz R (1995) Treatment of fuel oil and crude oil contaminated waters by ultrafiltration membranes. Desalination 02: 301-311.

17. Barrow G, Feltham R (1993) Cowan and Steele's manual for the identification of medical bacteria. (3rd edn), Cambridge University Press, Cambridge, England.

18. Sneath P (1986) Bergey's manuals on systematic bacteriology (vol. 2). Williams \& Wilkins, Baltimore, USA.

19. Tchobanoglous G, Burton FL, Stensel HD (2004) Wastewater Engineering: Treatment disposal reuse. McGraw-Hill, New York.
20. Li Q, Kang C, Zhang C (2005) Waste water produced from an oilfield and continuous treatment with an oil-degrading bacterium. Process Biochem 40: 873-877.

21. Leahy JG, Colwell RT (1990) Microbial degradation of hydrocarbons in the environment. Microbiol Rev 54: 305-315.

22. Hua X, Wang J, Wu Z, Zhang H, Li H, et al. (2010) A salt tolerant Enterobacter cloacae mutant for bioaugmentation of petroleum- and salt-contaminated soil. Biochem Eng J 49: 201-206.

23. Mahjoubi M, Jaouani A, Guesmi A, Amor SB, Jouini A, et al. (2013) Hydrocarbonoclastic bacteria isolated from petroleum contaminated sites in Tunisia: Isolation, identification and characterization of the biotechnological potential. New Biotechnol 30: 723-733.

24. Plociniczak MP, Płaza GA, Poliwoda A, Seget ZP (2014) Characterization of hydrocarbon-degrading and biosurfactant-producing Pseudomonas sp. P-1 strain as a potential tool for bioremediation of petroleum-contaminated soil. Environ Sci Pollut Res 21: 9385-9395.

25. Chen X, Wang M, Yang F, Tang W, Li X (2014) Isolation and characterization of xanthan-degrading Enterobacter sp. nov. LB37 for reducing the viscosity of xanthan in petroleum industry. World J Microbiol Biotechnol 30: 1549-1557.

26. Das K, Mukherjee AK (2007) Crude petroleum-oil biodegradation efficiency of Bacillus subtilis and Pseudomonas aeruginosa strains isolated from a petroleum-oil contaminated soil from North-East India. Bioresour Technol 98 1339-1345.

27. Han HL, Tang J, Jiang H (2008) Synergy between fungi and bacteria in fungibacteria augmented remediation of petroleum-contaminated soil. Environ Sci 29: 189-195

28. Das D, Baruah R, Roy AS, Singh AK, Boruah HPD, et al. (2015) Complete genome sequence analysis of Pseudomonas aeruginosa N002 reveals its genetic adaptation for crude oil degradation. Genomics 105: 182-190.

29. Tellez GT, Nirmalakhandan N, Gardea-Torresdey J (1995) Evaluation of biokinetic coefficients in degradation of oilfield produced water under varying salt concentrations. Wat Res 29:1711-1718.

30. Talaie KAR, Jafarzadeh HFN, Talaie KMR, Baheshti M (2010) The determination of biokinetic coefficients of crude oil biodegradation using Pseudomonas aeruginosa bacteria. Iran J Health \& Environ 3: 111-122.

31. Dong Z, Lu M, Huang W, Xu X (2011) Treatment of oilfield wastewater in moving bed biofilm reactors using a novel suspended ceramic biocarrier. $J$ Hazard Mater 196: 123-130.

32. Dareioti MA, Kornaros M (2014) Effect of hydraulic retention time (HRT) on the anaerobic co-digestion of agro-industrial wastes in a two-stage CSTR system. Bioresour Technol 167: 407-415.

33. Moussavi M, Ghorbanian M (2015) The biodegradation of petroleum hydrocarbons in an up-flow sludge blanket/fixed-film hybrid bioreactor under nitrate-reducing conditions: Performance evaluation and microbial identification. Chem Eng J 280: 121-131.

34. Ebrahimi M, Kazemi H, Mirbagheri SA (2016) An optimized biologica approach for treatment of petroleum refinery wastewater. J Environ Chem Eng 4: 3401-3408. 